DANCHENKO O.O.,

Postgraduate Student of Department "Entrepreneurship and Tourism",

Odessa National Maritime University,

st. Mechnikov, 34, Odessa, 65029

E-mail: lexdanuniversal@gmail.com

ORCID: 0000-0001-7467-4866

\title{
KEY PERFORMANCE INDICATORS OF A CREWING COMPANY ACTIVITY
}

Topicality. Enterprises must inculcate modern economic tools in the management practice to provide efficiency of their work. The universal set of parameters that can be used equally well for all kinds of activity without the exception is absent. The complexity of forming financial results of a crewing company activity and necessity of taking into account the specific features of its functioning require to research the key parameters of effectiveness concerning specifically crewing activity.

Aim and tasks. Identification of performance indicators (qualitative and quantitative) of the company, which will cover all aspects of the crewing company activity without any exceptions, taking into consideration the specifics of their activities and the peculiarities of formation of incomes and expenses for various types of crewing.

Research results. Most companies use traditional techniques to assess the competitive position on the market. Besides today, more and more attention is paid to valuing the company. In our view, to assess the work of a crewing company, it is necessary to focus on the so-called key performance indicators (KPIs). They are an element of a balanced system of parameters, which should have a set of indicators that can clearly identify the company's goals and the extent to which they are achieved. In particular, it is necessary to use both financial and non-financial indicators, to determine quantitative and qualitative KPIs, as well as perspective and actual indicators. A list of KPIs must be developed for each employee of a crewing company. Their number should not exceed 5-7 indicators. They all should be simple, understandable, clear and achievable. All KPIs should be known to all employees in order to ensure proper transparency, stimulate competition and motivate employees to develop.

Conclusion. Today, more emphasis is placed on traditional quantitative financial indicators that reflect the results achieved. In turn, promising indicators as KPIs provide a benchmark for company employees to the place of application of effort and reflect key improvements in the work of the crewing company. Therefore, it is necessary to make efforts and develop promising KPIs in order to determine what factors and how they affect the actual KPIs. This will help identify the specific services and processes that are key factors to the success of the company.

Keywords: crewing company, efficiency, efficiency criterion, key performance indicators, company value

ДАНЧЕНКО О.О.,

Аспірант кафедри «Підприємництво і туризм»

Одеський Національний морський університет,

вул. Мечникова, 34, м. Одеса, 65029

E-mail: lexdanuniversal@gmail.com

ORCID: 0000-0001-7467-4866

\section{КЛЮЧОВІ ПОКАЗНИКИ РЕЗУЛЬТАТИВНОСТІ ДІЯЛЬНОСТІ КРЮЇНГОВОЇ КОМПАНІї}

Актуальність. Підприємства для забезпечення ефективності своєї роботи повинні впроваджувати в практику господарювання сучасний економічний інструментарій. Універсальний набір показників, який з однаковим успіхом можна використовувати для всіх без виключення видів діяльності відсутній. Складний характер формування фінансових результатів роботи крюїнгової компанії та необхідність врахування специфіки ї̈ функиіонування вимагають дослідження ключових показників результативності стосовно саме крюёнгової діяльності.

Мета та завдання. Виявлення показників ефективності роботи компанї (якісних та кількісних), які висвітлять всі без виключення аспекти діяльності крюїнгової компанії з врахуванням специфріки їх діяльності та особливостей формування доходів та витрат при різних видах крюїнгу.

Результати. Більшість компаній для оцінки конкурентних позицій на ринку використовує традиційні методики. Також сьогодні все більше уваги приділяється оиіниі вартості компанії. На наш погляд, для оцінки роботи в крюїнговій компанії необхідно акцентувати увагу на так званих ключових показниках 
результативності. Вони є елементом збалансованої система показників, яка повинна мати комплекс індикаторів, які можуть чітко визначити иілі компанії та ступінь їх досягнення. Зокрема, необхідно використовувати як фінансові, так і нефінансові показники, визначити кількісні та якісні КРI, а також перспективні, так і фактичні показники. Для кожного прачівника крюїнгової компанї повинний бути розроблений перелік КРI. Їх кількість не повинна перевищувати 5-7 показників. Вони всі повинні бути простими, зрозумілими, однозначними та досяжними. Всі КРІ повинні бути відомі всім працівникам, щзоб забезпечити належну прозорість, стимулювати конкуренцію та мотивувати працівників компанії до розвитку.

Висновки. Сьогодні більше робиться акиент на традиійних кількісних фінансових показниках, які відображають досягнуті результати. В свою чергу перспективні показники в якості КРІ дають орієнтир працівникам компанії на місце прикладення зусиль $і$ відображають ключові поліпшення в роботі крюїнговоі компанії. Тому необхідно докласти зусиль і розробити перспективні КРІ, щоб визначити які фактори та яким чином впливають на фактичні КРІ. Це допоможе визначити конкретні послуги та процеси, які є ключовими факторами успіху компанії.

Ключові слова: крюїнгова компанія, ефективність, критерій ефективності, ключові показники результативності, вартість компанії

Постановка проблеми та їі зв'язок з важливими науковими та практичними завданнями. Вирішальне значення для визначення ефективності роботи крюїнгової компанії є вибір критеріїв їі оцінки. Вважається, що критерій економічної ефективності роботи компанії повинен відображати результати економічної діяльності, а також визначати ступінь досягнення мети ії функціонування. Критерій ефективності - це категорія, яка вказує на підстави оцінки ефективності, є ії мірилом.

Деякий час домінувала думка, що в якості критерію ефективності роботи компанії можна обмежуватися лише прибутком або рентабельністю. Але для оцінки ефективності необхідно залучати інші показники, тому що прибуток є абсолютним показником, який не дає уявлення про рівень ефективності, динаміку обсягу виробництва та не відображає результати використання ресурсів. Рентабельність, в свою чергу, є статичним показником і не дає уявлення про динаміку роботи компанії.

Також, може скластися ситуація, коли позитивне значення прибутку в бухгалтерській звітності може сусідити зі зниженням вартості компанії та погіршенням іiї позицій на ринку.

Універсальної регламентованої системи показників із заданими кількісними значеннями їх параметрів, придатних для оцінки ефективності діяльності підприємств любого виду економічної діяльності не існує. Для різних цілей за різних умов господарювання використовують різні критерії. Кожне підприємство відповідно до сфери господарювання і цілей діяльності обирає критерії ефективності та формує систему показників, за якими оцінюється відповідність своїм цілям.

Крюїнгові компанії виконують функції з надання послуг працевлаштування моряків на судна світового морського флоту. Тобто на їх роботу впливають фактори одразу з двох різних сфер господарювання: управління персоналом та судноплавство. Разом з тим, спостерігаються відмінності в механізмі формування фінансових результатів крюїнгових компаній при різних видах крюїнгу [5].

Тому, специфіка господарювання крюїнгової компанії та складні економічні процеси в рамках компанії обумовлюють актуальність теми дослідження.

Аналіз останніх публікацій по проблемі. В економічній літературі $[1,3,7,9,11,13,16]$ сформувалися наступні підходи до змісту та побудові критерію ефективності:

- максимум результату при оптимальній величині витрат;

- максимум результату при мінімумі витрат;

- максимум результату на одиницю витрат;

- мінімум витрат на одиницю результату (рис. 1).

В роботі [7] наведена класифікація груп показників ефективності за рівнем господарювання, змістом витрат, повнотою обліку складових, способом, стадією та розрахунку.

Різні підходи до оцінки ефективності роботи компанії обумовлені використання різних результатів. В роботі [12] пропонуються виділити такі підходи: ресурсний, витратний, ресурсновитратний, цільовий, системний, часовий, комбінований. Найбільш розповсюдженими є затратний $\mathrm{i}$ ресурсний підходи. 


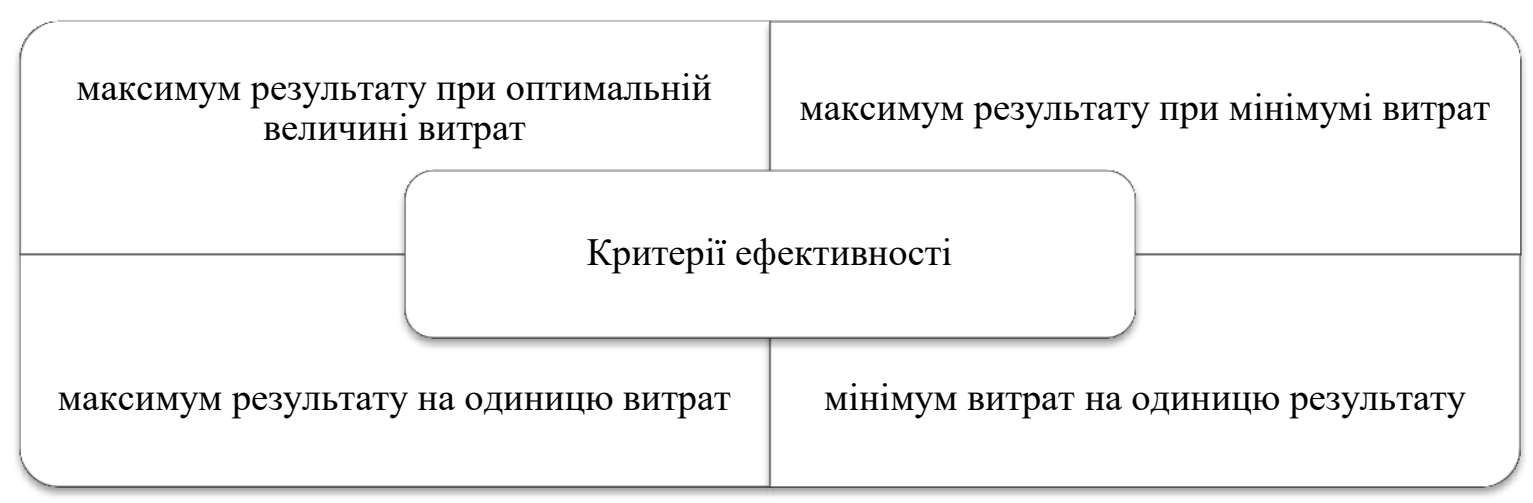

Джерело: [3]

Рис. 1. Підходи до формування критерію ефективності

Основна відмінність між підходами та в критеріях, які використовуються, полягає в різних поглядах на витрати і результати та моменти часу, до якого їх відносять.

Деякі автори пропонують в якості критерію ефективності використовувати єдиний комплексний показник, наприклад, вартість підприємства, якій агрегує в собі вплив всіх вище перелічених елементів $[4,11,14]$. Але найбільшого розповсюдження отримав багатокритеріальний підхід, за яким пропонується одночасно використовувати декілька критерії, які висвітлюють різні сфери діяльності компанії.

Виділення невирішених раніше частин загальної проблеми. Результат і витрати в різних ситуаціях можуть мати різні виміри: натуральний або грошовий. Особливо це стосується використання трудових ресурсів крюїнгової компанії, коли складно одразу в момент надання послуги визначити рівень витрати на них або результат від їх надання в грошовому вимірі $[6,15]$.

В цьому випадку повстає питання співвідношення результату та витрат у часі. Моменти несення витрат і отримання результату можуть бути значно рознесені у часі, іноді рахунок йде на місяці. Процес пошуку моряка та оцінка його відповідності замовленню судновласника, укладання договору та доставки моряка на борт судна та інші займають тривалий час. Тому при оцінці ефективності в крюїнговій діяльності мають значення не тільки розміри результатів і витрат, а також їх розташування у часі.

Формулювання цілей дослідження (постановка завдання). В даному дослідженні пропонується розглянути основні підходи до побудови системи показників підприємства. Та основі аналізу виявити показники ефективності роботи компанії (якісні та кількісні), які висвітлять всі сфери діяльності крюїнгової компанії 3 врахуванням специфіки їх діяльності та особливостей формування доходів та витрат при різних видах крюїнгу.

Виклад основних результатів та їх обгрунтування. Деякі автори висловлюються за можливість використання одного критерію ефективності, але найбільшого розповсюдження отримав багатокритеріальний підхід, за яким пропонується одночасно використовувати декілька критерії, які висвітлюють різні сфери діяльності компанії. Причому, всі критерії взаємопов'язані та можуть бути конкурентними, тобто зростання одного в короткостроковому періоді призводить до зниження другого.

Для того, щоб збалансувати різноспрямованість показників під час формування системи показників ефективності діяльності крюїнгової компанії необхідно дотримуватися єдиних принципів, що дасть можливість їх застосування при побудові механізму управління ефективністю діяльності крюїнгової компанії, який дозволить виявити та максимально ефективно використати резерви підвищення результативності всіх аспектів діяльності компанії (рис. 2).

Ефективність виробництва являє собою результат взаємодії елементів виробничого процесу: робочої сили, предметів праці і засобів праці. Тому систему показників ефективності виробництва пропонується складати 3 показників ефективності використання праці, основних фондів та матеріальних ресурсів [9]. Частіше ресурси ділять на такі складові: трудові, матеріальні та фінансові.

Для оцінки конкурентних позицій крюїнгової компанії на ринку можна використовувати традиційні методики. За можливості отримання відповідної інформації можна оцінити конкурентні позиції компанії за рівнем використання ресурсів. Оцінку ефективності використання ресурсів пропонується здійснити за допомогою показників, наведених в таблиці 1. 
одночасне використання декількох підходів та методів 3 подальшим порівнянням отриманих результатів;

комплексне використання кількісних та якісних показників;

найбільш повне відображення досягнутих результатів та паритетне висвітлення ефективності використання усіх видів ресурсів;

впровадження спеціальних методик оцінки для окремих сфер діяльності компанії та використання показників ефективності в управлінні всіма без виключення відділами та працівниками компанії;

використання показників ефективності для виявлення резервів зростання ефективності компанії

Рис. 2. Принципи побудови системи показників ефективності діяльності крюїнгової компанії Джерело: [13]

\section{Показники комплексної оцінки ефективності використання ресурсів крюїнгової компанії}

\begin{tabular}{|l|l|c|}
\hline \multicolumn{1}{|c|}{ Вид ресурсу } & \multicolumn{1}{|c|}{ Показники } & \multicolumn{1}{|c|}{ Об'єкт оцінки } \\
\hline \multirow{2}{*}{$\begin{array}{l}\text { Матеріальні } \\
\text { ресурси }\end{array}$} & $\begin{array}{l}\text { фондовіддача; } \\
\text { фондоємність; } \\
\text { фондоозброєність; } \\
\text { рентабельність фондів }\end{array}$ & $\begin{array}{c}\text { офісне устаткування } \\
\text { Трудгольне обладнання для }\end{array}$ \\
\hline прововки та тестування моряків
\end{tabular}

Джерело: розроблено автором за даними $[3,4,6,9]$

Сьогодні все більше уваги приділяється оцінці вартості компанії. В роботі [4] наведена порівняльна характеристика наступних показників вартості підприємства: 
- ринкова додана вартість (Market Value Added - MVA);

- додана грошова вартість (Cash Value Added - CVA);

- додана вартість для акціонерів (Shareholder's Value Added -SVA);

- показник доходності інвестицій на основі потоку грошових коштів (Cash Flow Return on Investment - CFROI);

- модель Едварда-Белла-Ольсона (Edward-Bell-Ohlson valuation model - EBO).

Цей підхід має багато прихильників, але він $€$ трудомістким та вимагає багато точної різнопланової інформації та високої кваліфікації від виконавців, i, як наслідок, дуже коштовний, що обмежує коло його використання.

На наш погляд, для оцінки роботи в крюїнговій компанії необхідно акцентувати увагу на так званих ключових показниках ефективності (англ. Key Performance Indicators, KPI).

Причиною появи цього поняття було введення Пітером Друкером в теорію управління системи «управління за цілями», яка міститься у врахуванні в розробці стратегії компанії можливих результатів та шляхів їх досягнення. За цією теорією при оцінці роботи компанії потребно не стільки оцінювати сам процес, скільки докласти зусиль до розробки показників (індикаторів), які будуть відображати відповідність цілям функціонування компанії $[1,7]$.

На це повинно бути спрямована робота всіх без виключення працівників. Та на досягнення загальної цілі компанії повинні бути налаштовані всі підрозділи компанії.

Вважається, що KPI дозволяють ефективно здійснювати моніторинг роботи всіх працівників, підрозділів і компанії в цілому. Дослівний переклад поняття «key performance indicators» $\epsilon$ «ключові показники ефективності». Це правильно 3 боку філології, але не зовсім вірно з боку економічного змісту показника.

Більш вірно розуміти під КРІ ключові показники результативності, тобто ступінь отримання результату на шляху досягнення цілей компанії. Це відповідає тлумаченню терміну в стандарті ISO 9000:2005, де performance має два значення: результативність і ефективність.

Таким чином, КРІ може дозволити визначити ступінь реалізації поставлених цілей. Сьогодні ці показники широко застосовуються при оцінці роботи персоналу та з метою його мотивації. В деяких випадках КРІ розглядають як всеохоплюючу систему оцінювання, що забезпечує досягнення оперативних і стратегічних цілей [10].

KPI i мотивація персоналу стали нерозривними поняттями, тому за допомогою даних показників можна створити досконалу та ефективну систему мотивації і стимулювання співробітників крюїнгової компанії.

КРІ класифікують за різними ознаками. Наприклад, в роботах $[2,7,8]$ пропонують виділити наступні групи КРІ:

1) цільові КРІ - це показники, які демонструють ступінь наближення компанії до поставленої цілі. Наприклад, зростання частки ринку, збільшення моряків, які відправлені в рейс, зростання кількості клієнтів - судноплавних компаній;

2) процесні КРІ - це показники, які відображують ефективність самого процесу без погіршення якості кінцевого продукту (роботи, послуги). Наприклад, скорочення витрат на доставку моряка на борт судна, скорочення часу виконання заявки від судновласника;

3) проектні КРІ - це показники, які відображають результати за конкретним проектом в межах діяльності всієї компанії. Наприклад, ефективність інвестицій в створення тренінгового центру (або придбання спеціалізованого устаткування), зростання доходів від навчання моряків за рахунок крюїнгової компанії;

4) зовнішні КРІ - це показники, на які неможливо безпосередньо вплинути, але які потрібно враховувати при розробці стратегії розвитку компанії та розробці їі КРІ. Наприклад, попит на моряків певної кваліфікації, середньо ринкова ставка комісійної винагороди за пошук моряка тощо.

Проведене дослідження різних видів КРІ дозволило запропонувати для крюїнгової компанії наступну класифікацію КРI:

1) за способом виміру:

- $\quad$ кількісні КРІ - це показники, які мають фінансового або фізичного змісту - гривні, особи, рейсо-дні тощо. Наприклад, прибуток, доходи, витрати, економія витрат, кількість моряків, відправлений в рейс тощо; 
- $\quad$ якісні КРІ - це показники, які не мають фінансовий або фізичний зміст - виражаються в балах, коефіцієнтах. Наприклад, імідж компанії, особистісні якості моряка (комунікативність, здатність до навчання) тощо;

2) за ступенем охоплення:

- $\quad$ індивідуальні КРІ - це індикатори роботи окремого працівника. Наприклад, продуктивність праці, кількість виконаних заявок, або проведених співбесід для крю-менеджерів. Для крюїнгових компаній, які працюють за схемою «крю-менеджмент» або «представництво судновласника» необхідно розробляти індивідуальні КРІ для моряків. Наприклад, кількість контрактів без зауважень 3 боку судновласника, кількість сертифікатів (достатній та понаднормовий обсяг);

- $\quad$ колективні (групові) КРІ - це індикатори роботи колективу всієї компанії, або окремого структурного підрозділу. Невеликі розміри більшості крюїнгових компаній вимагають багатозадачність для їх працівників і в цьому випадку важлива взаємодопомога. Наприклад, загальний обсяг виконаних заявок судновласників, середній термін виконання заявки для конкретного судновласника при повному крю-оперуванні судна;

3) за часом виникнення:

- фактичні (запізнілі) КРІ - це індикатори, які відображають фактичний стан та демонструють наслідки виконаних раніше дій. Наприклад, частка ринку, прибуток, кількість відправлених в рейс моряків тощо;

- $\quad$ перспективні (випереджальні) КРІ - це показники, результат яких знайде відображення в майбутньому в фактичних КРІ. Наприклад, база даних моряків сама по собі не дає сьогодні фактичного результату, але використання знайде відображення в кількості відправлених в рейс моряків та в обсязі отриманого прибутку;

4) за характером формування:

- $\quad$ фінансові КРІ - це фінансові показники роботи компанії, які пов'язані з фінансовими результатами іiі діяльності. В цю групу можна включити показники фінансового стану та фінансові результати роботи крюїнгової компанії. В цьому випадку необхідно враховувати різні характери формування фінансових результатів при різних видах крюїнгу. Наприклад, для чистого крюїнгу дохід може виступати КРІ, при крю-менеджменті це може бути лише прибуток, тому що в складі витрат значна часта приходиться на виплати морякам. I в якості КРІ в цьому випадку для окремих крюменеджерів можна призначати обсяг економії витрат на репатріацію моряка;

- $\quad$ нефінансові КРІ - це показники, які виражені не в грошовій формі. Це велика група показників, яку можна також розділити за трьома напрямками відповідно до збалансованої системи показників (Balanced scorecard - BSC) [7]:

а) відносини з клієнтами (ринок): кількість клієнтів-судновласників (операторів суден) кількість заявок, частка ринку, індекс лояльності клієнтів, індекс задоволеності клієнтів;

б) внутрішні бізнес-процеси: своєчасність обробки заявки судновласника, якість виконання заявки, кількість моряків, яким було відмовлено за невідповідність кваліфікації;

в) навчання і розвиток персоналу: володіння сучасним програмним забезпеченням за спеціальністю (для персоналу компанії і для моряків) тощо.

Основна складність для керівництва компанії міститься в правильному відборі КРІ для оцінки роботи компанії. 3 метою оцінювання результатів діяльності компанії слід застосовувати лише ті КPI, які забезпечують досягнення цілей компанії.

KРІ є елементом збалансованої система показників, яка повинна мати комплекс індикаторів, які можуть чітко визначити цілі компанії та ступінь їх досягнення. Зокрема, необхідно використовувати як фінансові, так і нефінансові показники, визначити кількісні та якісні КРІ, а також перспективні, так і фактичні показники.

Для кожного працівника крюїнгової компанії повинний бути розроблений перелік КРІ. Їх кількість не повинна перевищувати 5-7 показників. Вони всі повинні бути простими, зрозумілими, однозначними та досяжними.

Зокрема, в якості КРІ крю-менеджерів слід використовувати як індивідуальні (одиничні) КРІ, так і групові (командні). Особливо за умови роботи за повним крюїнг-менеджментом, коли здійснюється повне крю-оперування судна і необхідно виконати пошук та зміну всього екіпажу, або значної його частини. Цю роботу не може виконати один крю-менеджер, а від роботи одного члена групи забезпечення одного судна, залежать результати роботи інших членів групи - крю-менеджерів. 
Можливо використання одиничного, або комплексного показника, який дозволить врахувати різний ступінь впливу окремих факторів на підсумкове значення.

Підсумкове значення КРІ визначається як середньозважене за формулою (1):

$$
\mathrm{KPI}=\frac{\sum_{\mathrm{i}=1}^{n} \mathrm{KPI}_{\mathrm{i}} \cdot \alpha_{\mathrm{i}}}{n}
$$

де $\mathrm{KPI}_{\mathrm{i}}$ - коефіцієнт, значення i-го одиничного показника;

$\alpha_{\mathrm{i}}-$ вагомість і-го одиничного показника;

$\mathrm{n}$ - кількість одиничних показників.

Наприклад, в якості КРІ для крю-менеджерів для різних видів робіт пропонується обирати 3 наступних показників:

1) індивідуальні:

- кількість виконаних заявок;

- середній час виконання заявки;

- частка моряків, якім відмовила судноплавна компанія за невідповідність вимогам;

- темп росту бази даних моряків (взагалі та за окремими категоріями, на яких спеціалізується крюїнгова компанія);

- частка кількості наданих послуг в загальній кількості можливих послуг крюїнгової компанії;

- економія витрат на доставку моряка з/на борт судна при забезпеченні необхідної якості;

2) групові:

- с середній час виконання процедури пошуку моряка на заповнення вакансії за окремим проектом крю-оперування;

- частка моряків, якім відмовила судноплавна компанія за невідповідність вимогам;

- $\quad$ повнота та своєчасність заповнення вакансій за проектом.

В залежності від цілей діяльності керівництво крюїнгової компанії самостійно обирає КРІ для кожної окремої позиції в компанії, починаючи з охоронця, і закінчуючи, директором. Всі КРІ повинні бути відомі всім працівникам, щоб забезпечити належну прозорість, стимулювати конкуренцію та мотивувати працівників компанії до розвитку.

Висновки та перспективи подальших досліджень. Сьогодні більше робиться акцент на традиційних кількісних фінансових показниках, які відображають досягнуті результати. В свою чергу перспективні показники в якості КРІ дають орієнтир працівникам компанії на місце прикладення зусиль і відображають ключові поліпшення в роботі крюїнгової компанії. Традиційно так склалось, що більшість крюїнгових компаній для оцінки своєї роботи використовують фактичні показники, що не вимагає значних зусиль в зборі інформації. Розробка перспективних показників викликає більше труднощів, але це необхідно зробити, якщо компанія прагне до зростання, розвитку та досягнення цілей. Тому необхідно докласти зусиль і розробити перспективні КРІ, щоб визначити які фактори та яким чином впливають на фактичні КРІ. Це допоможе визначити конкретні послуги та процеси, які $є$ ключовими факторами успіху компанії. В подальшому планується скласти перелік КРІ для всіх ключових співробітників крюїнгової компанії.

\section{ЛITЕРАТУРА}

1. Houldsworth E., Jirasinghe. Managing and Measuring Employee Performance. London : Kogan Page, 2006. 245 p.

2. Вишнякова М. Как внедрить в компании систему КРІ // Люди и лидерство. Управление персоналом. 2012. № 2 (74). С. 22-28.

3. Войнаренко М.П., Скалюк Р.В. Управління фінансовими результатами промислових підприємств : монографія. Вінниця : ПП "ТД "Едельвейс і К", 2014. 188 с.

4. Говорушко Т.А., Климаш Н.I. Управління ефективністю діяльності підприємств на основі вартісно-орієнтованого підходу: монографія. К. : Логос, 2013. 204 с. 
5. Данченко О.О. Сутність та особливості формування фінансових результатів роботи крюїнгової компанії // Розвиток методів управління та господарювання на транспорті : зб. наук. праць. 2017. Вип. 2(59). С. 41-54.

6. Іванюта П.В. Управління ресурсами і витратами : навч. посіб. / За ред. д.е.н., проф. Іванюти С. М. К. : Центр навчальної літератури, 2009. 320 с.

7. Каплан Р., Нортон Д. Сбалансированная система показателей: от стратегии к действию. - 2-е изд. испр. и доп. / пер. с англ. М. : ЗАО «Олимп-Бизнес», 2003. 320 с.

8. Кулагин О. Как оценивать выполнение KPI по системе Performance Management? URL : http://www.e-xecutive.ru/career/hr-management/1455763-kak-ocenivat-vypolnenie-kpi-posisteme-

performance-management.

9. Олексюк О.І. Економіка результативності діяльності підприємства : монографія. К. : КНЕУ, 2008. $362 \mathrm{c}$.

10.Потій В.3., Куліш Г.П. Система управління ефективністю діяльності підприємств, іiі особливості і проблеми застосування в Україні // Науковий вісник Національної академії статистики, обліку та аудиту. 2017. № 1-2. С. 54 -59.

11.Синіговець О.М. Сучасні підходи до оцінки ефективності діяльності // Вісник НТУ «ХПІ». Серія: Технічний прогрес і ефективність виробництва. 2010. № 58. С. 8-13.

12.Тур О.В. Підходи науковців до визначення категорії ефективність // Наукові праці НУХТ. 2012. № 47. C. 149-156.

13.Цехла С.Ю. Принципы построения системы показателей оценки эффективности производства // Культура народов Причерноморья. 2000. № 12. С. 77-79.

14.Чернега О.М. Системний підхід до управління ефективністю діяльності організації // Науковий вісник. Одеський національний економічний університет. Всеукраїнська асоціація молодих науковців. 2013. № 16 (195). С. 45-54.

15.Чернишова I. Принципи формування культури стійкої результативності в компанії. URL : www.tmi.com.ua/ru/opinion/6.html.

16.Чорна Л.О. Прибуток як інтегральний показник господарської діяльності підприємства. // Ефективна економіка. 2013. № 1. URL : http://www.economy.nayka.com.ua/?op=1\&z=1997\&p=2.

\section{REFERENCES}

1. Houldsworth E. (Ed.). (2006). Managing and Measuring Employee Performance. London : Kogan Page [in English].

2. Vyshniakova M. (Ed.). (2012). Kak vnedryt v kompanyy systemu KRI [How to implement a KPI I system in a company]. Moskva : Upravlenye personalom [in Russian].

3. Voinarenko M.P. (Eds.). (2014). Upravlinnia finansovymy rezultatamy promyslovykh pidpryiemstv [Managing the financial results of industrial enterprises]. Vinnytsia : TD "Edelveis i K" [in Ukrainian].

4. Hovorushko T.A. (Eds.). (2013). Upravlinnia efektyvnistiu diialnosti pidpryiemstv na osnovi vartisno-oriientovanoho pidkhodu [Management of the effectiveness of partnerships on the basis of an internally-recognized partnership] Kyiv : Lohos [in Ukrainian].

5. Danchenko O.O. (2017). Sutnist ta osoblyvosti formuvannia finansovykh rezultativ roboty kriuinhovoi kompanii [The specialty and specialty of the form of financial results of the robot company] Odessa : ONMU [in Ukrainian].

6. Ivaniuta P.V. (Eds.). (2009). Upravlinnia resursamy i vytratamy. [Resource and cost management] Kyiv : Tsentr navchalnoi literatury [in Ukrainian].

7. Kaplan R. (Eds.). (2003). Sbalansyrovannaia systema pokazatelei: ot stratehyy k deistvyiu. [Balanced Scorecard: From Strategy to Action]. Moskva : Olymp-Byznes [in Russian].

8. Kulahyn O. (Ed.). (2016). Kak otsenyvat vipolnenye KPI po systeme Performance Management? [How do I assess performance performance by KPI?]. Moskva : e-xecutive.ru [in Russian].

9. Oleksiuk O.I. (Ed.). (2008). Ekonomika rezultatyvnosti diialnosti pidpryiemstva [Economic performance of the enterprise]. Kyiv : KNEU [in Ukrainian].

10. Potii V.Z. (Eds.). (2017). Systema upravlinnia efektyvnistiu diialnosti pidpryiemstv, yii osoblyvosti i problemy zastosuvannia v Ukraini [System of management of enterprise activity efficiency, its 
features and problems of application in Ukraine]. Kyiv : Naukovyi visnyk Natsionalnoi akademii statystyky, obliku ta audytu [in Ukrainian].

11. Synihovets O.M. (Ed.). (2010). Suchasni pidkhody do otsinky efektyvnosti diialnosti pidpryiemstva [Modern approaches to assessing the effectiveness of the enterprise Kharkiv]. Kharkiv : NTU «KhPI» [in Ukrainian].

12. Tur O.V. (Ed.). (2012). Pidkhody naukovtsiv do vyznachennia katehorii efektyvnist [Scientists approach to determining the category of efficiency]. Kyiv : NUKhT [in Ukrainian].

13. Tsekhla S.Iu. (Ed.). (2000). Pryntsypy postroenyia systemы pokazatelei otsenky эffektyvnosty proyzvodstva [Principles of building a system of indicators for assessing production efficiency]. Odesa : Kultura narodov Prychernomoria [in Russian]

14. Cherneha O.M. (Ed.). (2013). Systemnyi pidkhid do upravlinnia efektyvnistiu diialnosti orhanizatsii [The system approach to managing the effectiveness of the Odessa organization]. Odesa : Odeskyi natsionalnyi ekonomichnyi universytet [in Ukrainian].

15. Chernyshova I. (Ed.). (2014). Pryntsypy formuvannia kultury stiikoi rezultatyvnosti v kompanii [Principles of forming a culture of sustainable performance in the company] [Elektronnyi resurs]. Kyiv : Efektyvna ekonomika [in Russian].

16. Chorna L.O. (Ed.). (2013). Prybutok yak intehralnyi pokaznyk hospodarskoi diialnosti pidpryiemstva [Profit as an integral indicator of the economic activity of the enterprise]. Kyiv : Efektyvna ekonomika [in Ukrainian]. 